\title{
Reseña de Border Wars. The conflicts that will define our future
}

\author{
Review of Border Wars. The conflicts that will define our future
}

\author{
Xavier Ferrer Gallardo ${ }^{1}$
}

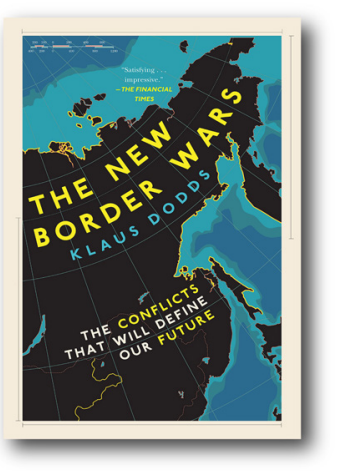

Autor: Klaus Dodds
Título: Border Wars. The conflicts that will define our future
Año: 2021
Ciudad: Londres
Editorial: Ebury Press
Páginas: 275 pp.
ISBN: 9781529102598
m.
Escrito por Klaus Dodds, profesor de geopolítica de la Universidad Royal Holloway de Londres, este texto es algo así como un manual de instrucciones para viajar al futuro de los conflictos geopolíticos y para empezar a vislumbrar un conjunto de nuevas guerras fronterizas cuyas bases se están gestando en la actualidad. Es, en otras palabras, una suerte de guía para interpretar las luchas de poder sobre el territorio que van a condicionar las relaciones internacionales en los años venideros. Uno de los mensajes centrales del libro y que conviene tener en cuenta es este: en la actualidad, y de la mano del desarrollo tecnológico, el espacio para la disputa potencial se está ensanchando a gran velocidad. En consecuencia, en el futuro cercano las controversias fronterizas podrán desencadenarse en un abanico de puntos cada vez más amplio: desde en las cada vez menos insondables profundidades de las aguas internacionales ricas en minerales, hasta en el espacio ultraterrestre -también fuente potencial de apetitosos recursos estratégicos-, pasando por las zonas del planeta más contundentemente azotadas por el cambio climático (glaciares derretidos, polos en deshielo, regiones inundadas debido al aumento del nivel del mar, etc.).
El libro de Dodds también reserva espacio para visitar el trasfondo histórico de escenarios fronterizos (terrestres y marítimos) que se antojan en eterna disputa, como los de Taiwán o Palestina, o los de la antigua colonia española del Sahara Occidental (p. 145). En relación a este último escenario, Dodds recuerda cómo, mientras (no) llega el referéndum que de acuerdo con los establecido por Naciones Unidas debería desatascar el conflicto, el territorio en disputa se halla divido en dos partes separadas por una buffer zone: la sección occidental controlada por Marruecos con acceso a fosfatos y a recursos pesqueros, y la sección oriental controlada por el Frente Polisario y sin acceso a dichos recursos. En esta tesitura, Dodds argumenta que la Unión Europea - y en especial los dos antiguos colonizadores, España y Francia- ha sido reacia a presionar en favor del referéndum a fin de no agriar su relación con Marruecos, que resulta esencial en el marco de las estrategias de control de las migraciones y el tráfico de drogas (p. 161).

Redactado con un estilo a caballo entre el manuscrito académico y el texto divulgativo, el libro se estructura en torno a nueve capítulos. Estos cubren un amplio espectro de cuestiones concernientes a

1 Departamento de Humanidades, Universidad Pompeu Fabra, España. xavier.ferrer@upf.edu 
los nuevos retos de gestión (y fricción) que plantean las líneas de delimitación espacial trazadas sobre mapas: fronteras no reconocidas; fronteras glaciares que se desdibujan en tiempos antropocénicos; tierras de nadie deseadas por muchos; fronteras inteligentes ávidas de datos biométricos; gestión fronteriza en contextos pandémicos; etc. El capítulo que aborda las dinámicas fronterizas en el espacio ultraterrestre resulta particularmente interesante. Se trata de un terreno hasta la fecha poco explorado en el ámbito de los estudios fronterizos.

El libro nos ayuda a recordar hasta qué punto, incluso en la Luna, resulta harto complicado desprenderse de la trampa territorial del Estado-Nación. Es cierto que antes del alunizaje de Armstrong en 1969, los Estados Unidos y la Unión Soviética habían acordado la prohibición de apropiarse de los cuerpos celestes. Efectivamente, el pequeño-gran paso de Armstrong fue realizado en nombre de la humanidad y no en nombre de su país. Sin embargo, seguro que ustedes también recuerdan la icónica imagen de la bandera americana plantada en la Luna. En cualquier caso, el compromiso de no apropiación (de prohibición de reivindicaciones de soberanía) había quedado reflejado en el Tratado del Espacio de 1967 -cuyo clarificador nombre completo es "Tratado sobre los principios que deben regir las actividades de los Estados en la exploración y utilización del espacio ultraterrestre, incluso la Luna y otros cuerpos celestes sobre el espacio ultraterrestre". Debido al contenido de dicho tratado, el estandarte de barras y estrellas clavado en la luna no equivale a un título de propiedad para Washington.
Según el artículo II del Tratado "el espacio ultraterrestre, incluso la Luna y otros cuerpos celestes, no podrá ser objeto de apropiación nacional por reivindicación de soberanía, uso u ocupación, ni de ninguna otra manera". Pero como ironiza Dodds (p. 196), todo era más fácil a finales de los 60, cuando se redactó el tratado y la tecnología era mucho más rudimentaria. Hoy, en plena nueva carrera por la superioridad armamentística en el espacio -y con una rivalidad por el control de los recursos ultraterrestres al alza y con muchos más actores (públicos y privados) participando en el juego-, habrá que ver hasta dónde aguantan las costuras de lo acordado hace seis décadas. La tecnología actual facilita enormemente el acceso y la explotación de recursos mineros situados en cuerpos celestes como la Luna. Y, en este contexto, renunciar a la apropiación (o a la explotación de dichos recursos) representa un ejercicio de contención geopolítica de gran calado. La tentación para reinterpretar lo acordado en el pasado es mayúscula.

Dodds vaticina que, a medida que los estragos de la emergencia climática se vayan acrecentando, las partes de la tierra que sigan siendo habitables -y cuyos recursos sigan siendo explotables- se irán convirtiendo en puntos de creciente presión geopolítica (p.246). En cualquier caso, con independencia de lo que vaya a suceder en aquellos puntos del planeta sobre los que planea la sombra del conflicto fronterizo (Ártico, Antártida, fondos marinos de aguas internacionales, etc.), no debería extrañarnos si alguna de las controversias fronterizas del futuro cercano se libra más allá de los confines de la tierra. El libro de Klaus Dodds ayuda a ponernos en situación. 